\title{
Endocannabinoid System as Therapeutic Target of PTSD: A Systematic Review
}

\author{
Luca Steardo, Jr. ${ }^{1, *}$, Elvira Anna Carbone ${ }^{2}(0)$, Giulia Menculini ${ }^{3}$, Patrizia Moretti ${ }^{3}$, Luca Steardo ${ }^{4,5}$ and \\ Alfonso Tortorella ${ }^{3}$ \\ 1 Psychiatric Unit, Department of Health Sciences, University Magna Graecia of Catanzaro, \\ Viale Tommaso Campanella, 115, 88100 Catanzaro, Italy \\ 2 Department of Medical and Surgical Sciences, University Magna Graecia of Catanzaro, \\ Viale Tommaso Campanella, 115, 88100 Catanzaro, Italy; elvira.carbone@libero.it \\ 3 Department of Psychiatry, University of Perugia, Piazzale Lucio Severi, 1, 06132 Perugia, Italy; \\ giuliamenculini@gmail.com (G.M.); patrizia.moretti@unipg.it (P.M.); alfonso.tortorella@unipg.it (A.T.) \\ 4 Department of Physiology and Pharmacology, Faculty of Pharmacy and Medicine, Sapienza University of \\ Rome, Piazzale Aldo Moro, 5, 00185 Rome, Italy; lucasteardo@uniroma1.it \\ 5 Department of Psychiatry, Giustino Fortunato University, 12, 82100 Benevento, Italy \\ * Correspondence: steardo@unicz.it
}

Citation: Steardo, L., Jr.; Carbone, E.A.; Menculini, G.; Moretti, P.; Steardo, L.; Tortorella, A. Endocannabinoid System as Therapeutic Target of PTSD: A Systematic Review. Life 2021, 11, 214 https://doi.org/10.3390/ life11030214

Academic Editor: Friedrich Jung, Christian Doerig,

Gustavo Caetano-Anollés, Edgar Lehr and Ronald S. Oremland

Received: 29 January 2021

Accepted: 5 March 2021

Published: 9 March 2021

Publisher's Note: MDPI stays neutral with regard to jurisdictional claims in published maps and institutional affiliations.

Copyright: (C) 2021 by the authors. Licensee MDPI, Basel, Switzerland. This article is an open access article distributed under the terms and conditions of the Creative Commons Attribution (CC BY) license (https:// creativecommons.org/licenses/by/ $4.0 /)$.

\begin{abstract}
Post-Traumatic Stress Disorder (PTSD) is a complex disorder involving dysregulation of stress-related hormones and neurotransmitter systems. Research focused on the endocannabinoid system (eCBS) for anxiety and stress regulation, cognitive and emotional responses modulation and aversive memories extinction, leading to the hypothesis that it could represent a possible alternative treatment target for PTSD. In this systematic review, we summarize evidence about the efficacy and safety of medicinal cannabidiol (CBD), $\Delta^{9}$-tetrahydrocannabinol ( $\Delta^{9}$-THC), and nabilone in PTSD treatment. The PRISMA statement guidelines were followed. A systematic literature search was conducted in MEDLINE/PubMed, Scopus and Web of Science by two independent researchers, who also performed data extraction and quality assessment. Among the initial 495 papers, 234 were screened for eligibility and 10 were included. Studies suggested that different medicinal cannabinoids at distinct doses and formulations could represent promising treatment strategies for the improvement of overall PTSD symptomatology as well as specific symptom domains (e.g., sleep disorders, arousal disturbances, suicidal thoughts), also influencing quality of life, pain and social impact. Although there is a robust rationale for treatment with drugs that target the eCBS and the results are promising, further studies are needed to investigate the safety and efficacy profile of their prolonged use.
\end{abstract}

Keywords: endocannabinoids; CBD; cannabidiol; THC; $\Delta^{9}$-tetrahydrocannabinol; nabilone; PTSD; PTSD treatment; systematic review

\section{Introduction}

Post-Traumatic Stress Disorder (PTSD) is a psychiatric disorder that may occur in people after experiencing or witnessing a traumatic event. This nosographic entity was previously included in the Diagnostic and Statistical Manual of Mental Disorders, fourth edition (DSM-IV) as an anxiety disorder, whereas in the latest edition (DSM-5) PTSD was classified under a category named "Trauma and stress-related disorders" [1,2]. With a prevalence varying up to $5 \%$ in high-income countries, PTSD is often associated with significant comorbidity rates, relevant risk of chronicization, and substantial economic burden [3].

In the context of a maladaptive response to a traumatic stressor [4,5], individuals can develop symptoms such as persistent intrusive thoughts associated with the traumatic event, incessant avoidance of stimuli related to the traumatic event, negative changes in 
cognition and mood linked to the event, and significant and long-lasting alterations in arousal and reactivity attributable to the traumatic event. These symptoms can last for more than one month or persist for several months, causing significant distress due to poor life quality, reduced social skills, and functioning problems [1].

Although PTSD is caused by a psychologically traumatic environmental event and consequently it is considered a psychological phenomenon, many studies have indicated biological abnormalities, not observed in controls, which have been regarded either as risk factors for the development of the disease or as potential targets for therapeutic interventions. There have been detected changes across different stress hormones and neurotransmitter systems in the pathophysiology of PTSD. Serotoninergic, noradrenergic, glutamatergic, GABAergic, neuro-peptidergic systems and dysfunctions of the hypothalamus-adrenal axis have been reported to contribute to the disease onset and progression, even if no alteration of a single system taken individually can explain by itself the complex pathobiology underlying the disorder. In this context, and mainly based on findings from preclinical studies, a growing interest in terms of neurochemical interactions has been attracted by the endocannabinoid system (eCBS), since it makes up an extensive interconnected network of neuromodulators that controls synaptic neurotransmitter release. As it has been involved in several physiological and pathophysiological processes including synaptic plasticity, pain, memory processes, stress, and emotion regulation, its potential implication in the pathophysiology of PTSD has been regarded of considerable interest [6]. Indeed, the eCBS plays an important role in regulating anxiety and stress and is involved in the modulation of cognitive and emotional responses [7], as well as in the extinction of aversive memories [8]. This system is essential for the development of synaptic plasticity in response to endogenous and environmental salient events $[9,10]$, determining specific learning and emotional responses related to traumatic experiences [11]. Endocannabinoids regulate affective and emotional states and participate in memory consolidation, retrieval, and extinction $[12,13]$. It has been demonstrated that the learning processes regarding aversive memories are dysregulated after a traumatic event, as occurs in subjects affected by PTSD [14]. Evidence suggests that the hypothalamic-pituitary-adrenal (HPA) system, which is essential for stress adaption, also plays a role in the pathophysiology of the disorder. Indeed, the HPA axis is chronically activated in patients with PTSD [15]. There is a bidirectional and functional interplay between eCBS and HPA systems: the eCBS can modulate the HPA axis function restraining the effects of severe stress on its activation [16-18], whilst the release of glucocorticoids in response to a stressor contributes to eCBS signaling deficiencies, thus facilitating PTSD symptoms [19].

Given the heterogeneity of the disorder and its economic and social burden, PTSD represents a challenge for safe and effective treatment [20]. Despite more psychological treatment approaches for PTSD [21,22], the Food and Drug Administration (FDA) approved only two pharmacological treatments for PTSD, the Selective Serotonin Reuptake Inhibitors (SSRIs) paroxetine and sertraline [23] that do not display certain effectiveness in producing a clinical remission and may be responsible for several side effects [24,25], which can sometimes reduce treatment compliance [26].

Recent research has focused on the eCBS as a possible alternative target to treat PTSD $[27,28]$. Evidence highlighted a reduction of endocannabinoid levels [29] and cannabinoid receptor type 1 (CB1) receptors up-regulation in the brain of PTSD patients [30]. Thus, the use of components derived from Cannabis sativa as cannabidiol (CBD) and $\Delta^{9}$ tetrahydrocannabinol $\left(\Delta^{9}-\mathrm{THC}\right)$ has drawn increasing interest as a possible alternative approach to treat PTSD. To reinforce this assumption several studies support cannabis use as self-medication to cope with PTSD symptoms [4,31].

While CBD is known to bind the G-protein-coupled receptor GPR55, the transient receptor potential of vanilloid type- 1 channel (TRPV1), the 5-HT1a receptor, and the $\alpha 3$ and $\alpha 1$ adrenergic receptors, we will focus on the CB1 and CB2 receptors, since they are relevant to the Central Nervous System (CNS) [32]. Preclinical and clinical studies suggested that $\mathrm{CBD}$, acting also as a negative allosteric modulator of endogenous ligands of CB1 and 
CB2, may present a beneficial effect in PTSD treatment, enhancing the consolidation of explicit fear extinction and attenuating aversive memories of the traumatic event [33-36]. Moreover, $\Delta^{9}$-THC, a CB1 and CB2 partial agonist, showed a safe and well-tolerated profile in chronic PTSD with a significant improvement in global symptom severity, sleep quality, frequency of nightmares, and hyperarousal symptoms [37]. More recently, nabilone, a synthetic cannabinoid that activates CB1, was reported to reduce the frequency and intensity of nightmares in PTSD patients [38-41].

Despite promising preliminary evidence, no reviews to our best knowledge have systematically summarized the effectiveness of cannabinoids or cannabino-mimetic in the treatment of PTSD. Previous literature reviewed the evidence about the eCBS as a potential target for PTSD treatment and prevention, but without following a systematic approach and focusing also on pathophysiological correlates of the disorder [28,42,43]. In consideration of what is stated above, the present systematic review is aimed at summarizing the existent evidence on medicinal cannabinoids (e.g., THC, CBD, nabilone) in the treatment of PTSD in humans, critically analyzing and discussing both the efficacy and safety of these treatment approaches.

\section{Materials and Methods}

The present review was conducted following the Preferred Reporting Items for Systematic Reviews and Meta-Analyses (PRISMA) statement [44].

\subsection{Literature Search}

A systematic search of the electronic databases MEDLINE/PubMed, Scopus, and Web of Science was performed from inception to 23 November 2020 by entering the following search string: $(((((($ cannabidiol) $)$ R cannabinoid $)$ OR cannabinol) OR endocannabinoid) OR tetrahydrocannabinol) OR nabilone) OR palmitoyl-ethanolamide) AND ((posttraumatic stress disorder) OR PTSD) AND treatment.

Two investigators (EAC and GM) independently conducted the literature search, title/abstract screening, and full-text review. The reference list of selected articles was hand-screened to search for additional literature. Discrepancies were resolved through consensus and, whenever a final decision could not be achieved, a third investigator was consulted (LS jr).

\subsection{Study Selection}

Original studies investigating the effectiveness of medicinal cannabinoids in the treatment of PTSD diagnosed according to the DSM criteria were deemed eligible for inclusion, according to the PICO methodology. Literature considering specific symptoms of PTSD as treatment outcomes was also evaluated for the present review, with no language limits. Grey literature was included whenever sufficient information was provided. Articles presenting only an opinion or hypothesis without empirical investigation, reviews, letters to the editor, and commentaries were excluded. Case series were included if sufficient information was given. Studies reporting data on genetic and molecular aspects in animal models were not deemed eligible for the present review. As for studies with overlapping samples, more than one article was considered for inclusion if reporting on different aspects of the considered outcomes.

\subsection{Quality Assessment}

Considering the heterogeneity of included studies, the Grading of Recommendations, Assessment, Development and Evaluation (GRADE) approach was used to rate the quality of the evidence [45]. This was done by two reviewers (EAC and GM) and disagreements were resolved via discussion with one further reviewer (LS jr). The quality of evidence was rated as "high", "moderate," "low," or "very low" based on GRADE rating standards. A "high-quality" rating indicates that future research is very unlikely to change existing evidence and that the true effect is similar to the estimated effect; a "moderate-quality" 
and a "low-quality" rating indicates that future research may change/is likely to change the evaluation results, respectively; a "very low-quality" rating indicates that it is highly uncertain about the existing evidence and that the true effect is likely to be substantially different from the estimated effect.

\subsection{Data Extraction}

Two blind researchers (EAC and GM) performed data extraction. In order to address the objectives of the review, the following information was extracted from the included papers: first author name, year and country of publication, analyzed period, study design, study sample (number, age, and gender), treatment provided, comparator group (e.g., placebo, active), study measure and outcomes. Reviewers extracted data independently from each relevant study and data was checked by all reviewers in case of discrepancies.

\subsection{Risk of Bias Assessment}

The quality of the evidence provided by the eligible studies was assessed by the two independent researchers (GM and EAC). The risk of bias for randomized controlled trials (RCTs) was evaluated with the Revised Cochrane Risk of Bias Tool (RoB 2.0) [46].

\section{Results}

\subsection{Search Results}

The initial search returned 495 records (MEDLINE/PubMed $=182$, Scopus $=182$, Web of Science $=131$ ). Among these, 261 were identified as duplicates and were subsequently excluded. Title and abstract screening were performed for the remaining 234 papers, 14 of which were included in the further evaluation. The full-text examination led to the selection of 8 papers. The hand-screening of references led to the inclusion of two additional records. Subsequently, 10 papers were deemed eligible for the present review (see flowchart in Figure 1).

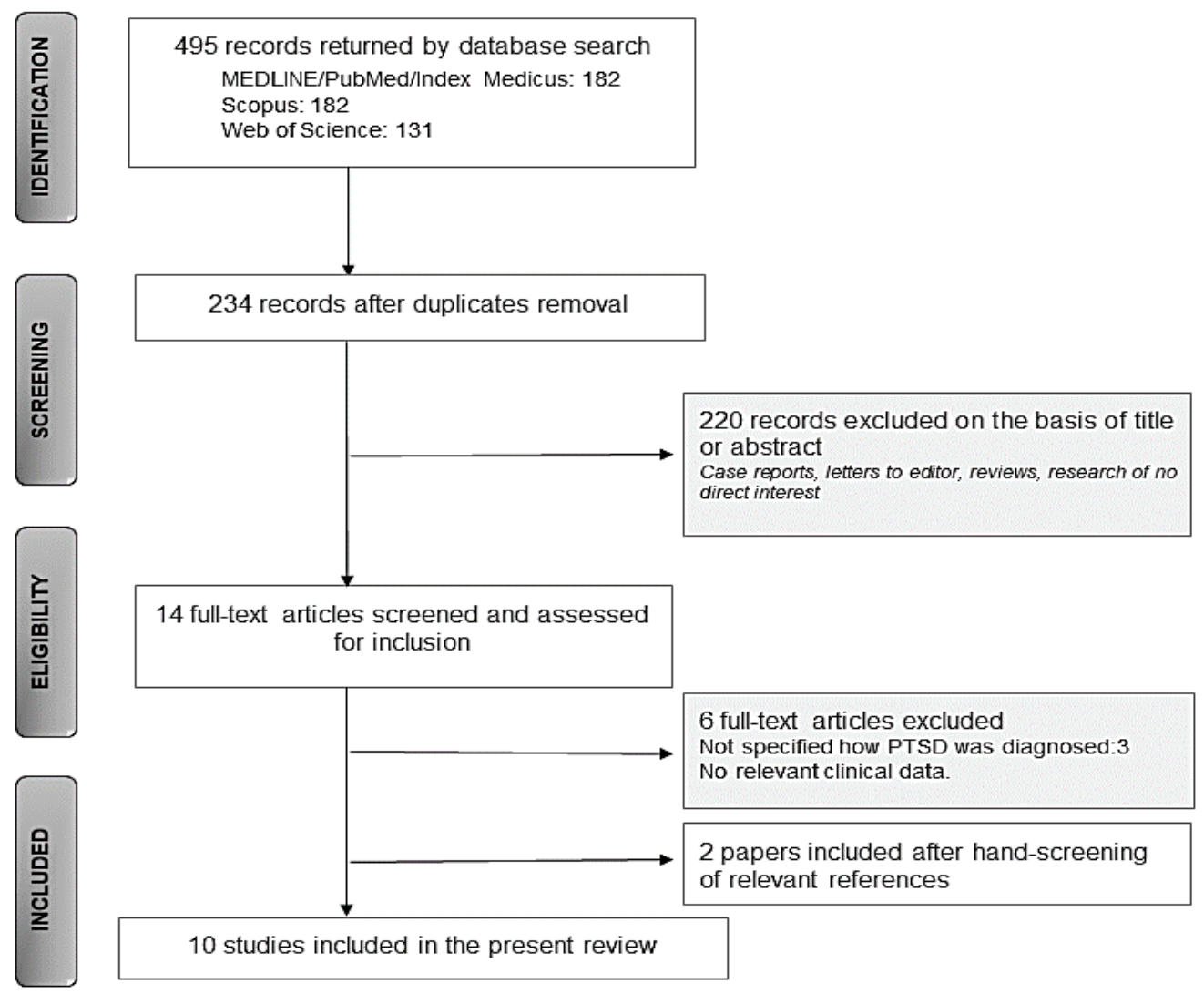

Figure 1. The PRISMA flow chart. 


\subsection{Content Results}

All studies were published over a period from 2009 to 2019 and mainly conducted in the US or Canada. Diagnosis of PTSD was made using DSM-IV or DSM- 5 criteria. We included four retrospective studies [40,47-49], two observational studies [50,51], two openlabel studies [37,38], and two randomized, double-blind, placebo-controlled studies [39,52]. Most of the studies included male subjects and two studies evaluated veterans or military personnel [39,48]. The mean age of participants ranged between 32 and 52 years [37,40,52]. Treatment with CBD only [47], THC only [37,52], medical cannabis (THC and CBD at variable percentages) [48-51], and nabilone [38-40] was evaluated in included studies considering different formulations (e.g., liquid oil spray, capsule), gradual titration and mean dose. The mean dose of CBD was $9 \mathrm{mg} / \mathrm{d}$ (range 1-16) for liquid oil spray formulation and $25 \mathrm{mg} / \mathrm{d}$ (range 25-100) for capsule [47]; THC was used at $7.5 \mathrm{mg}$ in capsule formulation or oil $0.1 \mathrm{cc}$ bid raising to $0.2 \mathrm{cc}$ bid $(0.1 \mathrm{cc}=2.5 \mathrm{mg}$ ) [37] while medical cannabis (THC and CBD at variable percentages) was started at $1 \mathrm{~g} / \mathrm{d}$ and titrated based on clinical response to a maximum dose of $10 \mathrm{~g} / \mathrm{d}[48,49]$ and a mean dose of $1.2-3 \mathrm{~g} / \mathrm{d}[50,51]$. The start dose of nabilone was $0.5-2 \mathrm{mg}$ and titrated weekly to a maximum of $3-4 \mathrm{mg} / \mathrm{d}$ (range $0.5-6 \mathrm{mg}$ ) [38-40]. Only two studies used a placebo comparator group [39,52]. The treatment had variable duration with a minimum of three weeks [37] and a maximum of 43 weeks [40] of drug administration in the acute phase [52]. Regarding psychiatric measures, changes in PTSD Checklist for the DSM-5 (PCL-5) [47], Post-Traumatic ChecklistCivilian Version (PCL-C) [40], Clinician-Administered PTSD Scale (CAPS) [37,39,49,51], Clinical Global Impressions (CGI) [37,39], Pittsburgh Sleep Quality Index (PSQI), Nightmare Effects Survey (NES), Nightmare Effects Survey (NFQ) [37], Well Being Questionnaire (WBQ) [39], and Quality of Life Scale (QOLS) [51] scores were evident. Only one study evaluated the modulation of the amygdala and pre-frontal activation under an acute low dose of THC in patients with and without PTSD and healthy controls (HC) [52]. Considering outcomes, a reduction in PTSD symptoms (e.g., nightmares, intrusive thoughts, anxiety, arousal) as measured by psychometric scores was detected, as well as a decrease of suicidal thoughts. A decrease of PTSD social impact score from 6.6 to 2.7 as reported in clinical charts [48] and an improvement in the quality of life in QOLS score [51] and WBQ score [39] after treatment was also demonstrated. Therefore, results showed that cannabinoids (e.g., THC, CBD, nabilone) may be effective in treating PTSD symptoms as clinical response and psychometric scores demonstrated. Furthermore, acute administration of a low dose of cannabinoid acted on corticolimbic responses to threat-related processing. Data from included studies are reported in Table 1. 
Table 1. The main characteristics of included studies.

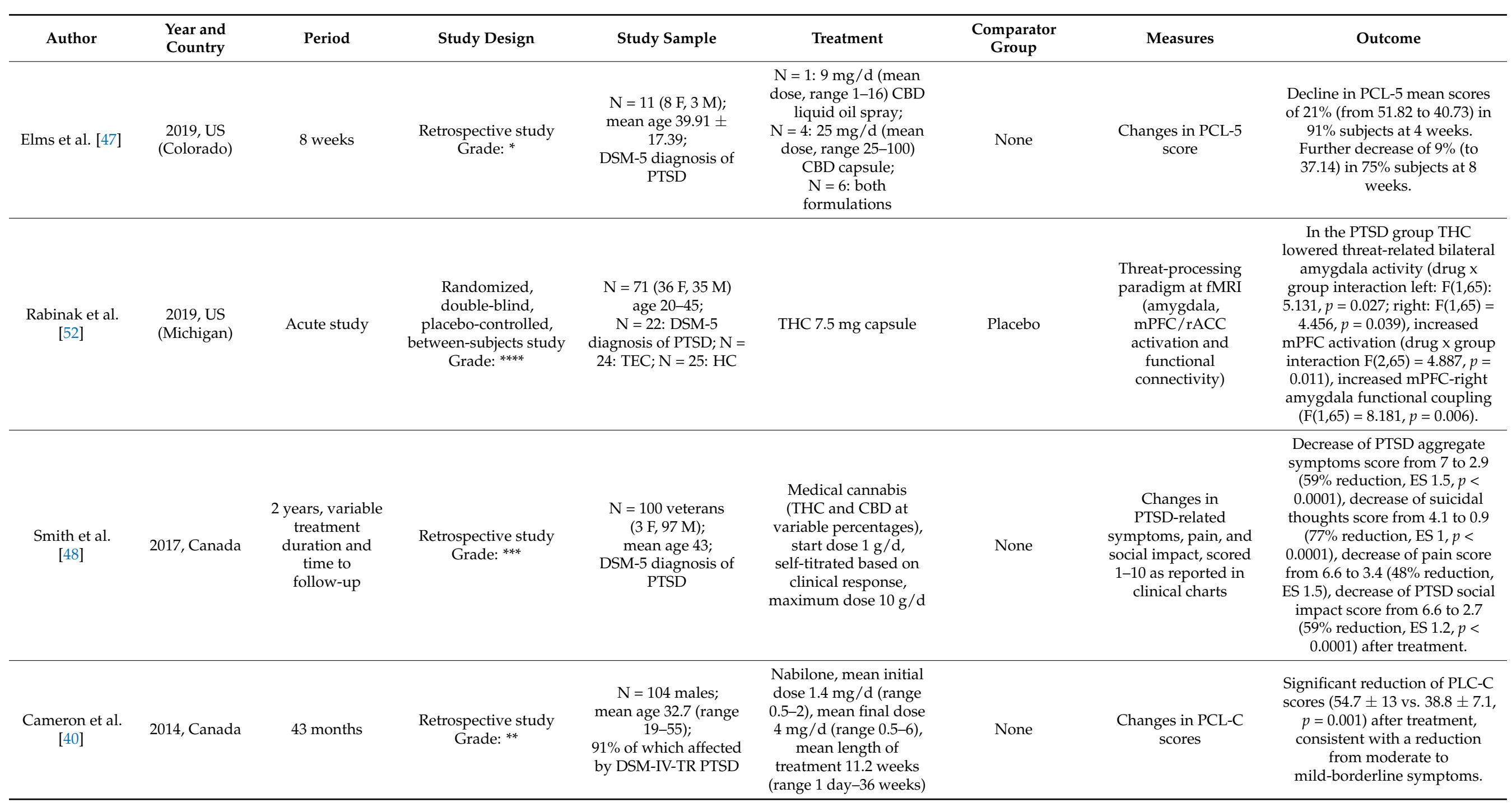


Table 1. Cont.

\begin{tabular}{|c|c|c|c|c|c|c|c|c|}
\hline Author & $\begin{array}{l}\text { Year and } \\
\text { Country }\end{array}$ & Period & Study Design & Study Sample & Treatment & $\begin{array}{c}\text { Comparator } \\
\text { Group }\end{array}$ & Measures & Outcome \\
\hline $\begin{array}{l}\text { Greer et al. } \\
\text { [49] }\end{array}$ & $\begin{array}{c}\text { 2014, US } \\
\text { (California) }\end{array}$ & 30 months & $\begin{array}{l}\text { Retrospective study } \\
\text { Grade: ** }\end{array}$ & $\begin{array}{c}\mathrm{N}=80 \text { adults; } \\
\text { DSM-IV diagnosis of } \\
\text { PTSD }\end{array}$ & $\begin{array}{l}\text { Medical cannabis } \\
\text { (THC and CBD at } \\
\text { variable percentages), } \\
\text { start dose } 1 \mathrm{~g} / \mathrm{d} \text {, } \\
\text { self-titrated based on } \\
\text { clinical response, } \\
\text { maximum dose } 10 \mathrm{~g} / \mathrm{d}\end{array}$ & None & $\begin{array}{l}\text { Changes in CAPS } \\
\text { scores }\end{array}$ & $\begin{array}{c}\text { Decrease in total CAPS score } \\
(22.5 \pm 16.9 \text { vs. } 98.8 \pm 17.6, p< \\
0.0001) \text { in subjects using } \\
\text { cannabis. Significant } \\
\text { reductions in CAPS symptom } \\
\text { cluster scores (Cannabis } \times \\
\text { Cluster: } \mathrm{F}(2,158)=39.87, p< \\
0.0001) .\end{array}$ \\
\hline $\begin{array}{c}\text { Roitman et al. } \\
{[37]}\end{array}$ & 2014, Israel & 3 weeks & $\begin{array}{l}\text { Non-randomized, } \\
\text { open-label, adjusted } \\
\text { doses, study } \\
\text { Grade: }{ }^{* * *}\end{array}$ & $\begin{array}{c}\mathrm{N}=10(3 \mathrm{~F}, 7 \mathrm{M}) \\
\text { mean age } 52.3 \pm 8.3 ; \\
\text { DSM-IV PTSD } \\
\text { diagnosis }\end{array}$ & $\begin{array}{l}\mathrm{TCH} \text { oil } 0.1 \mathrm{cc}(=2.5 \\
\mathrm{mg}) \text { bid, after } 2 \text { days } \\
\text { raised to } 0.2 \mathrm{cc}(=5 \mathrm{mg}) \\
\text { bid }\end{array}$ & None & $\begin{array}{l}\text { Changes in CAPS, CGI, } \\
\text { PSQI, NFQ, NES scores }\end{array}$ & $\begin{array}{c}\text { Significant decrease in CAPS } \\
\text { arousal }(32.3 \pm 4.73 \text { vs. } 24.3 \pm \\
9.11, p<0.02), \text { CGI-S }(6 \pm 0.47 \\
\text { vs. } 4.9 \pm 0.99, p<0.02), \text { NFQ } \\
\text { frequency of nightmares }(0.81 \\
\pm 0.55 \text { vs. } 0.44 \pm 0.41, p<0.04) \\
\text { NES }(32.2 \pm 11.29 \text { vs. } 22.9 \pm \\
8.7, p<0.002), \text { PSQI }(17.20 \pm \\
2.65 \text { vs. } 13.9 \pm 4.48, p<0.05) \\
\text { scores after treatment with } \\
\text { THC. }\end{array}$ \\
\hline $\begin{array}{l}\text { Bonn-Miller } \\
\text { et al. [50] }\end{array}$ & $\begin{array}{l}\text { 2013, US } \\
\text { (California) }\end{array}$ & Not specified & $\begin{array}{c}\text { Cross-sectional study } \\
\text { Grade: ** }\end{array}$ & $\begin{array}{c}\mathrm{N}=217(26.7 \% \mathrm{~F}, 73.3 \% \\
\mathrm{M}) ; \\
\text { mean age } 41.2 \pm 14.9 \\
\text { (range } 18-74 \text { years); } \\
40 \text { (18.9\%) affected by } \\
\text { PTSD }\end{array}$ & $\begin{array}{l}\text { Medical cannabis, } \\
\text { flexible-dose (mean } \\
\text { use: } 3 \text { times/d, 9-12 } \\
\text { g/week) }\end{array}$ & None & $\begin{array}{l}\text { Subjective help } \\
\text { received from medical } \\
\text { cannabis as measured } \\
\text { by a 5-point-likert scale }\end{array}$ & $\begin{array}{c}\text { Traumatic intrusions predicted } \\
\text { cannabis helpfulness (beta } 0.22, \\
p<0.01) \text {, as well as the use of } \\
\text { cannabis for social anxiety } \\
\text { problems }(p<0.004) .\end{array}$ \\
\hline
\end{tabular}


Table 1. Cont.

\begin{tabular}{|c|c|c|c|c|c|c|c|c|}
\hline Author & $\begin{array}{l}\text { Year and } \\
\text { Country }\end{array}$ & Period & Study Design & Study Sample & Treatment & $\begin{array}{l}\text { Comparator } \\
\text { Group }\end{array}$ & Measures & Outcome \\
\hline Reznik [51] & 2012, Israel & 3 years & $\begin{array}{c}\text { Naturalistic } \\
\text { observational study } \\
\text { Grade: }{ }^{* *}\end{array}$ & $\begin{array}{c}\mathrm{N}=167 \\
25 \text { pure PTSD, } \\
43 \text { PTSD + clinical } \\
\text { depression, } \\
\text { 88 PTSD + chronic pain }\end{array}$ & $\begin{array}{c}\text { Medicinal cannabis } \\
(20-25 \% \mathrm{THC}) \text {, range } \\
2-3 \mathrm{~g} / \mathrm{d}\end{array}$ & None & $\begin{array}{l}\text { Changes in CAPS, } \\
\text { QOLS, CGI-I scores }\end{array}$ & $\begin{array}{l}\text { Significant improvement in } \\
\text { QOLS and pain scores in most } \\
\text { cases, with some positive } \\
\text { changes in CAPS scores. The } \\
\text { majority of improved subjects } \\
\text { belonged to comorbidity } \\
\text { groups. }\end{array}$ \\
\hline Fraser [38] & 2009, Canada & $\begin{array}{l}2 \text { years of clinical } \\
\text { observation; } \\
\text { flexible duration } \\
\text { of treatment } \\
\text { with nabilone } \\
\text { (depending on } \\
\text { the clinical } \\
\text { response) }\end{array}$ & $\begin{array}{l}\text { Non-randomized, } \\
\text { open-label study } \\
\text { Grade: }{ }^{* * *}\end{array}$ & $\begin{array}{c}\mathrm{N}=47(27 \mathrm{~F}, 20 \mathrm{M}) ; \\
\text { mean age } 44 \pm 9 ; \\
\text { DSM-IV-TR diagnosis } \\
\text { of PTSD, } \\
\text { treatment-resistant } \\
\text { nightmares }\end{array}$ & $\begin{array}{c}\text { Nabilone } 0.5 \mathrm{mg} \text { (start } \\
\text { dose) before bedtime, } \\
\text { then titrated; doses } \\
\text { were kept below } 6 \\
\mathrm{mg} / \mathrm{d}\end{array}$ & None & $\begin{array}{l}\text { Changes in the } \\
\text { intensity of } \\
\text { PTSD-related } \\
\text { nightmares }\end{array}$ & $\begin{array}{l}34(72 \%) \text { subjects experienced } \\
\text { total cessation or significant } \\
\text { reduction of nightmares. } \\
\text { Nabilone discontinuation was } \\
\text { successful in } 4(8 \%) \text { subjects, } \\
\text { whilst the others experienced a } \\
\text { recurrence of nightmares. }\end{array}$ \\
\hline
\end{tabular}

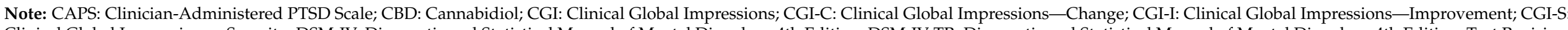

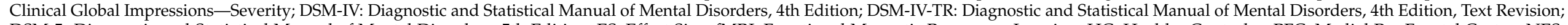

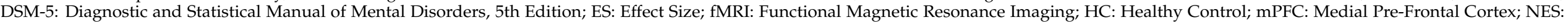

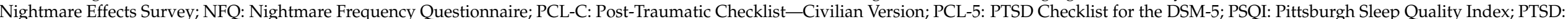

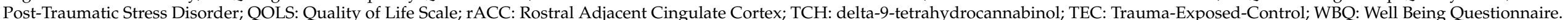
GRADE: * very low; ${ }^{* *}$ low; ${ }^{* * *}$ moderate; ${ }^{* * * *}$ high. 


\subsection{Quality and Risk of Bias Assessment}

According to the GRADE approach, only two studies presented high quality, whilst most of the included research showed low-to-moderate quality. Detailed information concerning quality assessment is included in Table 1. According to the RoB 2.0 tool, there were some concerns about the possible risk of bias for included RCTs, mainly affecting the randomization process and data reporting (Table 2). Indeed, in the study with randomized, double-blind, placebo-controlled cross-over design [39] information about the sequence allocation was not available, whilst in the randomized, double-blind, placebo-controlled, between-subjects study [52] outcome data was not available for all randomized subjects.

Table 2. Evaluation of the risk of bias for Randomized Studies using the RoB 2.0 Tool.

\begin{tabular}{cccccc}
\hline References & Overall Risk $^{\text {a }}$ & Randomization & Intervention & Missing Data & $\begin{array}{c}\text { Outcome } \\
\text { Measurement }\end{array}$ \\
\hline $\begin{array}{c}\text { Rabinak et al. } \\
\text { (2019) [52] }\end{array}$ & $+/-$ & - & - & $+/-$ & - \\
\hline $\begin{array}{c}\text { Jetly et al. } \\
\text { (2014) [39] }\end{array}$ & $+/-$ & $+/-$ & - & - & - \\
\hline
\end{tabular}

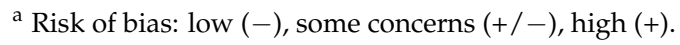

\section{Discussion}

Studies included in the present review suggested that different medicinal cannabinoids at distinct doses and formulations could represent promising treatment strategies for PTSD-related symptoms, also presenting an impact on the quality of life in this population. Particularly, not only did treatment with cannabinoids determine an overall improvement of PTSD symptomatology [37,39,40,47-49,51], but it also influenced specific symptom domains, namely sleep disorders [37-39], arousal disturbances [37], and suicidal thoughts [48]. Noteworthy, a significant reduction of pain $[48,51]$ and social impact [48], as well as an improvement in quality of life and well-being [39,51], were demonstrated.

A better understanding of the possible mechanisms through which such treatments could influence the clinical expression of PTSD is of particular interest since most medications used in clinical practice have the main aim of relieving symptom severity without specifically targeting underlying biological pathways [53].

To note, CB receptors are differently expressed in brain areas and nervous cells: CB1 receptors are highly expressed in the cortex, basal ganglia, hippocampus, hypothalamus, and cerebellum while CB2 receptors are mostly expressed in the immune and gastrointestinal cells and they may modulate central and peripheral regions [9]. CBD acts on both CB1 and CB2 receptors with lower affinity for $\Delta^{9}-T H C$, producing less adverse effects (e.g., tachycardia, sedation, hunger) but significantly decreasing fear-memory consolidation and anxiety symptoms of PTSD, possibly due to its action on limbic and paralimbic areas $[54,55]$. CBD can also exert an agonistic action on the 5-HT1a receptor that may explain its antiemetic and anxiolytic-like properties, on the GPR55 enhancing neuronal excitability, and on the TRPV1, highly localized in the hippocampus, reducing anxiety and aversive memories [32]. The inverse agonist action on CB2 may also explain the anti-inflammatory effects [56]. $\Delta^{9}$-THC acts through neuronal presynaptic CB1 receptors as a partial agonist and inhibits directly or indirectly ongoing neurotransmitter release such as dopamine, glutamate, and acetylcholine [55] in the nucleus accumbens, prefrontal cortex, hippocampus, and amygdala with a consequential reduction in hypervigilance, anxiety, insomnia, nightmares, and extinction deficits related to PTSD [57,58]. Nabilone, a synthetic THC analog, is a CB1 receptor agonist and has been demonstrated to reduce recurrent nightmares, flashbacks, and improve sleep time even if the exact mechanism is not yet understood [38-41,59].

The efficacy of medicinal cannabinoids in reducing overall PTSD symptomatology might indeed find a possible explanation in their mechanism of action, given their modu- 
latory influence on different neurotransmitter systems, as demonstrated by the presence of $\mathrm{CB}$ receptors in pre-synaptic GABAergic and glutamatergic terminations, but also in noradrenergic, serotoninergic, and dopaminergic axon terminals $[27,60]$.

Noteworthy, PTSD pathophysiology relies on abnormalities that cut across different neural circuits, involving distinct neurotransmitters at the same time [61]. Given the heterogeneity of PTSD symptomatology, belonging to several domains as stated in the diagnostic criteria, molecules that could target more than one system could represent adequate candidates for acting on different clinical features [28], thus reducing overall illness severity.

Besides, the eCBS plays a key role in the process of extinguishing aversive memories, which is mainly mediated by CB1 and could be thus facilitated by CBD administration, as already suggested by animal models, with further confirmation in human studies [34,62]. Similar mechanisms could also explain the improvement in arousal symptom clusters, that appear to be activated by emotional processing of fear-elicited stimuli and altered responses to trauma-related cues [63]. Interestingly, only one among the included studies considered the administration of CBD at variable doses [47], whilst in the remaining studies subjects were treated with different formulations of medicinal cannabis containing THC and $\mathrm{CBD}$ at different percentages, or synthetic compounds. Consequently, aversive memories extinction is not expected to be the only mechanism possibly explaining the efficacy of medicinal cannabis in reducing PTSD symptoms. The effect on global PTSD symptomatology might be mediated by the reduction of HPA axis hyperactivation following eCBS signaling enhancement. This could be related to the expression of $\mathrm{CB}$ receptors in brain areas that modulate stress, as well as emotional responses to fear and reward, such as the amygdala, pre-frontal cortex, and hippocampus [64]. Particularly, CB1 in the pre-frontal cortex plays a significant role in threat-related responses by modulating the amygdala region [65]. Noteworthy, one of the selected studies showed how the administration of medicinal THC in PTSD subjects could influence cortico-limbic circuitry, also reducing amygdala reactivity in response to potentially threatening stimuli [52]. This result should hopefully be replicated for CBD and synthetic Cannabis-derived compounds, to evaluate whether slightly different actions on eCBS receptors may underpin different effects on brain circuitry. Moreover, future studies should better clarify functional correlates of treatment with medications acting on the eCBS to provide further explanations about their mechanism of action in reducing PTSD symptoms. Furthermore, specific symptom clusters were targeted by treatment with medicinal cannabis in some of the included studies. Particularly, sleep problems such as PTSD-related nightmares were significantly improved by THC oil and nabilone at a maximum dose of 3-6 mg. This result may be of clinical relevance since nightmares are not typically targeted by medications that appear to be efficient in treating other PTSD symptoms [66]. The efficacy of Cannabis derivates in ameliorating sleep disorders was already elucidated by animal studies, with specific effects on sleep duration and depth varying based on means and site of administration (e.g., intraperitoneal, amygdala, brain ventriculus, etc.) $[67,68]$. Diverse effects of CBD were over time detected depending on medication doses, with higher doses up to $160 \mathrm{mg} /$ day increasing sedative-hypnotic effects $[69,70]$. Such effects were hypothesized to be mediated by the monoaminergic system since CBD appeared to increase the expression of c-Fos in the dorsal raphe nuclei [71]. Furthermore, CBD can increase Anandamide (AEA) concentration by blocking the AEA membrane transporter (AMT) or the Fatty Acid Amide Hydrolase (FAAH) enzyme, which catalyzes AEA hydrolysis, increasing time of sleep and of slow-wave phase that is physiologically fostered by this endogenous CB1 ligand [72]. Nevertheless, most preclinical research focused mainly on the administration of $\mathrm{CBD}$, which acts as a negative allosteric modulator of CB1 [73], while the included studies considered effects of TCH and its derivates, possibly operating as a partial agonist of the receptor [74]. In consideration of their different actions on endogenous receptors, further studies on PTSD populations should better clarify different actions of THC and CBD on sleep disorders. This could be of particular interest also due to the frequent association that specific arousal distur- 
bances may present with nightmares and sleep abnormalities, with evidence for nabilone improving such disturbances in non-PTSD populations [75].

Notably, pain indexes were significantly reduced after treatment with nabilone at a maximum dose of $6 \mathrm{mg} / \mathrm{d}$ and medicinal cannabis with 20-25\% THC component at $2-3 \mathrm{~g} / \mathrm{d}$. The use of medicinal cannabis for chronic pain symptoms finds wide support in the medical literature given the modulatory effects of the eCBS on inflammation and pain-processing pathways in the central and peripheric nervous systems, mainly relying on CB2 expression in peripheral tissues and immune cells [76-79]. Pain is frequently associated with PTSD clinical features, with evidence about mutual influences that such symptoms may exert. Future research focused on this specific comorbidity may elucidate whether treatment with cannabinoids could represent a favorable treatment strategy for selected PTSD subjects with specific comorbidities.

Despite promising results on the improvement of quality of life, as well as reduction of the social impact of PTSD, the use of medicinal cannabinoids in this population could also present negative consequences on general well-being due to their abuse and dependence potential $[59,80]$. Indeed, subjects affected by PTSD demonstrated the tendency to use cannabis as a form of self-medication due to its anxiolytic and sedative properties [57,81,82], also displaying high rates of comorbid substance-related disorders [83]. Except for cannabidiol which is a phyto-derivative of cannabis devoid of any psychotropic effect, the recreational use of cannabis, particularly synthetic compounds with high THC content, may elicit the emergence of psychotic and anxiety symptoms, as well as cognitive dysfunctions [84-86]. Conversely, side effects of medicinal cannabinoids (e.g., dizziness, headache, fatigue, gastrointestinal problems) presented mild-to-moderate severity and were relatively well-tolerated, supporting the assumption that subjects with PTSD may consider them less burdensome than approved medications [87]. Future research should hopefully clarify the long-term effects of such treatments to provide further data concerning their safety profile.

Evidence reported by the included studies presents several limitations. First, most of the considered research is based on small sample sizes, with restricted generalizability of findings. Moreover, heterogeneous samples determine major limitations in the among-study comparability of results. Included studies show low-to-moderate quality and moderate-to-high risk of bias in most cases, which suggests that further studies are expected to address methodological issues to provide solid bases for the use of medicinal cannabinoids in clinical practice. In addition, the retrospective or observational design of most of the included studies precludes conclusions about causality. Only a few RCTs were conducted and comparators were used only in two cases, despite repeated calls for controlled studies that may elucidate the effectiveness of new medications in PTSD treatment $[61,88]$. Finally, medications were assumed for short periods in most cases and no follow-up data were thus provided. Other randomized, placebo-controlled studies designed or head-to-head comparator studies are therefore needed.

\section{Conclusions}

Post-Traumatic Stress Disorder is a particularly heterogeneous clinical entity since it does not invariably exhibit in all subjects the same variety of symptoms and neither do they have similar severity. Moreover, it frequently occurs in comorbidity with other physical or mental disorders. Although there is a robust rationale for the treatment with drugs active, directly or indirectly, on the cannabinoid system and the results to date are promising, further studies are needed to investigate the safety and efficacy profile of their prolonged use. Hopefully, continued research could provide clinicians with novel therapeutic options for a disease that currently is treated with drugs of limited efficacy.

Author Contributions: Conceptualization, L.S.J.; literature search, E.A.C. and G.M.; writingoriginal draft preparation, L.S.J., E.A.C. and G.M.; writing—review and editing, L.S.J., P.M., L.S. and A.T.; supervision, A.T. All authors have read and agreed to the published version of the manuscript. 
Funding: This research received no external funding.

Institutional Review Board Statement: Not applicable.

Informed Consent Statement: Not applicable.

Conflicts of Interest: The authors declare no conflict of interest.

\section{References}

1. American Psychiatric Association. Diagnostic and Statistical Manual of Mental Disorders: DSM-5, 5th ed.; American Psychiatric Association: Washington, DC, USA, 2013.

2. American Psychiatric Association. DSM-IV-TR: Diagnostic and Statistical Manual of Mental Disorders, 4th ed.; American Psychiatric Association: Washington, DC, USA, 2000.

3. Watson, P. PTSD as a Public Mental Health Priority. Curr. Psychiatry Rep. 2019, 21. [CrossRef] [PubMed]

4. Passie, T.; Emrich, H.M.; Karst, M.; Brandt, S.D.; Halpern, J.H. Mitigation of post-traumatic stress symptoms by Cannabis resin: A review of the clinical and neurobiological evidence. Drug Test. Anal. 2012, 4, 649-659. [CrossRef]

5. Berardi, A.; Schelling, G.; Campolongo, P. The endocannabinoid system and Post Traumatic Stress Disorder (PTSD): From preclinical findings to innovative therapeutic approaches in clinical settings. Pharmacol. Res. 2016, 111, 668-678. [CrossRef]

6. Kelmendi, B.; Adams, T.G.; Yarnell, S.; Southwick, S.; Abdallah, C.G.; Krystal, J.H. PTSD: From neurobiology to pharmacological treatments. Eur. J. Psychotraumatol. 2016, 7, 31858. [CrossRef] [PubMed]

7. Schiavon, A.P.; Bonato, J.M.; Milani, H.; Guimarães, F.S.; Weffort de Oliveira, R.M. Influence of single and repeated cannabidiol administration on emotional behavior and markers of cell proliferation and neurogenesis in non-stressed mice. Prog. Neuro-Psychopharmacol. Biol. Psychiatry 2016, 64, 27-34. [CrossRef]

8. Marsicano, G.; Wotjak, C.T.; Azad, S.C.; Bisogno, T.; Rammes, G.; Cascioll, M.G.; Hermann, H.; Tang, J.; Hofmann, C.; Zieglgänsberger, W.; et al. The endogenous cannabinoid system controls extinction of aversive memories. Nature 2002, 418, 530-534. [CrossRef]

9. Lu, H.C.; MacKie, K. An introduction to the endogenous cannabinoid system. Biol. Psychiatry 2016, 79, 516-525. [CrossRef]

10. Castillo, P.E.; Younts, T.J.; Chávez, A.E.; Hashimotodani, Y. Endocannabinoid Signaling and Synaptic Function. Neuron 2012, 76, 70-81. [CrossRef]

11. Riebe, C.J.; Pamplona, F.; Kamprath, K.; Wotjak, C.T. Fear relief-toward a new conceptual frame work and what endocannabinoids gotta do with it. Neuroscience 2012, 204, 159-185. [CrossRef] [PubMed]

12. Trezza, V.; Campolongo, P. The endocannabinoid system as a possible target to treat both the cognitive and emotional features of post-traumatic stress disorder. Front. Behav. Neurosci. 2013, 7. [CrossRef] [PubMed]

13. De Bitencourt, R.M.; Pamplona, F.A.; Takahashi, R.N. A current overview of cannabinoids and glucocorticoids in facilitating extinction of aversive memories: Potential extinction enhancers. Neuropharmacology 2013, 64, 389-395. [CrossRef] [PubMed]

14. Davis, M.; Whalen, P.J. The amygdala: Vigilance and emotion. Mol. Psychiatry 2001, 6, 13-34. [CrossRef]

15. Dunlop, B.W.; Wong, A. The hypothalamic-pituitary-adrenal axis in PTSD: Pathophysiology and treatment interventions. Prog. Neuro-Psychopharmacol. Biol. Psychiatry 2019, 89, 361-379. [CrossRef]

16. Ganon-Elazar, E.; Akirav, I. Cannabinoids prevent the development of behavioral and endocrine alterations in a rat model of intense stress. Neuropsychopharmacology 2012, 37, 456-466. [CrossRef]

17. Patel, S.; Roelke, C.T.; Rademacher, D.J.; Cullinan, W.E.; Hillard, C.J. Endocannabinoid signaling negatively modulates stressinduced activation of the hypothalamic-pituitary-adrenal axis. Endocrinology 2004, 145, 5431-5438. [CrossRef] [PubMed]

18. Micale, V.; Drago, F. Endocannabinoid system, stress and HPA axis. Eur. J. Pharmacol. 2018, 834, 230-239. [CrossRef]

19. Gray, J.M.; Wilson, C.D.; Lee, T.T.Y.; Pittman, Q.J.; Deussing, J.M.; Hillard, C.J.; McEwen, B.S.; Schulkin, J.; Karatsoreos, I.N.; Patel, S.; et al. Sustained glucocorticoid exposure recruits cortico-limbic CRH signaling to modulate endocannabinoid function. Psychoneuroendocrinology 2016, 66, 151-158. [CrossRef]

20. Hidalgo, R.B.; Davidson, J.R.T. Posttraumatic stress disorder: Epidemiology and health-related considerations. J. Clin. Psychiatry 2000, 61, 5-13. [PubMed]

21. Wynn, G.H. Complementary and Alternative Medicine Approaches in the Treatment of PTSD. Curr. Psychiatry Rep. 2015, 17. [CrossRef]

22. Robertson, M.; Humphreys, L.; Ray, R. Psychological Treatments for Posttraumatic Stress Disorder: Recommendations for the Clinician Based on a Review of the Literature. J. Psychiatr. Pract. 2004, 10, 106-118. [CrossRef] [PubMed]

23. Akiki, T.J.; Abdallah, C.G. Are there effective psychopharmacologic treatments for PTSD? J. Clin. Psychiatry 2019, 80, 18ac12473. [CrossRef] [PubMed]

24. Bernardy, N.C.; Friedman, M.J. Psychopharmacological Strategies in the Management of Posttraumatic Stress Disorder (PTSD): What Have We Learned? Curr. Psychiatry Rep. 2015, 17, 564. [CrossRef] [PubMed]

25. Berger, W.; Mendlowicz, M.V.; Marques-Portella, C.; Kinrys, G.; Fontenelle, L.F.; Marmar, C.R.; Figueira, I. Pharmacologic alternatives to antidepressants in posttraumatic stress disorder: A systematic review. Prog. Neuro-Psychopharmacol. Biol. Psychiatry 2009, 33, 169-180. [CrossRef]

26. Shin, H.J.; Greenbaum, M.A.; Jain, S.; Rosen, C.S. Associations of psychotherapy dose and SSRI or SNRI refills with mental health outcomes among veterans with PTSD. Psychiatr. Serv. 2014, 65, 1244-1248. [CrossRef] 
27. Ronan, P.J.; Wongngamnit, N.; Beresford, T.P. Molecular Mechanisms of Cannabis Signaling in the Brain. In Proceedings of the Progress in Molecular Biology and Translational Science; Elsevier: Amsterdam, The Netherlands, 2016; Volume 137, pp. $123-147$.

28. Sbarski, B.; Akirav, I. Cannabinoids as therapeutics for PTSD. Pharmacol. Ther. 2020, 211, 107551. [CrossRef]

29. Morena, M.; Patel, S.; Bains, J.S.; Hill, M.N. Neurobiological Interactions Between Stress and the Endocannabinoid System. Neuropsychopharmacology 2016, 41, 80-102. [CrossRef] [PubMed]

30. Neumeister, A.; Normandin, M.D.; Pietrzak, R.H.; Piomelli, D.; Zheng, M.Q.; Gujarro-Anton, A.; Potenza, M.N.; Bailey, C.R.; Lin, S.F.; Najafzadeh, S.; et al. Elevated brain cannabinoid CB 1 receptor availability in post-traumatic stress disorder: A positron emission tomography study. Mol. Psychiatry 2013, 18, 1034-1040. [CrossRef] [PubMed]

31. Cougle, J.R.; Bonn-Miller, M.O.; Vujanovic, A.A.; Zvolensky, M.J.; Hawkins, K.A. Posttraumatic stress disorder and cannabis use in a nationally representative sample. Psychol. Addict. Behav. 2011, 25, 554-558. [CrossRef] [PubMed]

32. Thompson, M.D.; Sakurai, T.; Rainero, I.; Maj, M.C.; Kukkonen, J.P. Orexin receptor multimerization versus functional interactions: Neuropharmacological implications for opioid and cannabinoid signalling and pharmacogenetics. Pharmaceuticals 2017, 10, 79. [CrossRef] [PubMed]

33. Bitencourt, R.M.; Takahashi, R.N. Cannabidiol as a therapeutic alternative for post-traumatic stress disorder: From bench research to confirmation in human trials. Front. Neurosci. 2018, 12. [CrossRef] [PubMed]

34. Das, R.K.; Kamboj, S.K.; Ramadas, M.; Yogan, K.; Gupta, V.; Redman, E.; Curran, H.V.; Morgan, C.J.A. Cannabidiol enhances consolidation of explicit fear extinction in humans. Psychopharmacology 2013, 226, 781-792. [CrossRef]

35. Uhernik, A.L.; Montoya, Z.T.; Balkissoon, C.D.; Smith, J.P. Learning and memory is modulated by cannabidiol when administered during trace fear-conditioning. Neurobiol. Learn. Mem. 2018, 149, 68-76. [CrossRef] [PubMed]

36. Morena, M.; Berardi, A.; Colucci, P.; Palmery, M.; Trezza, V.; Hill, M.N.; Campolongo, P. Enhancing Endocannabinoid Neurotransmission Augments the Efficacy of Extinction Training and Ameliorates Traumatic Stress-Induced Behavioral Alterations in Rats. Neuropsychopharmacology 2018, 43, 1284-1296. [CrossRef]

37. Roitman, P.; Mechoulam, R.; Cooper-Kazaz, R.; Shalev, A. Preliminary, open-label, pilot study of add-on oral $\Delta 9$ tetrahydrocannabinol in chronic post-traumatic stress disorder. Clin. Drug Investig. 2014, 34, 587-591. [CrossRef]

38. Fraser, G.A. The use of a synthetic cannabinoid in the management of treatment-resistant nightmares in posttraumatic stress disorder (PTSD). CNS Neurosci. Ther. 2009, 15, 84-88. [CrossRef] [PubMed]

39. Jetly, R.; Heber, A.; Fraser, G.; Boisvert, D. The efficacy of nabilone, a synthetic cannabinoid, in the treatment of PTSD-associated nightmares: A preliminary randomized, double-blind, placebo-controlled cross-over design study. Psychoneuroendocrinology 2015, 51, 585-588. [CrossRef] [PubMed]

40. Cameron, C.; Watson, D.; Robinson, J. Use of a synthetic cannabinoid in a correctional population for posttraumatic stress disorder-related insomnia and nightmares, chronic pain, harm reduction, and other indications: A retrospective evaluation. J. Clin. Psychopharmacol. 2014, 34, 559-564. [CrossRef]

41. Cowling, T.; MacDougall, D. Nabilone for the Treatment of Post-Traumatic Stress Disorder: A Review of Clinical Effectiveness and Guidelines; Canadian Agency for Drugs and Technologies in Health: Ottawa, ON, Canada, 2019; pp. 1-16.

42. Ney, L.J.; Matthews, A.; Bruno, R.; Felmingham, K.L. Cannabinoid interventions for PTSD: Where to next? Prog. NeuroPsychopharmacol. Biol. Psychiatry 2019, 93, 124-140. [CrossRef] [PubMed]

43. Cohen, J.; Wei, Z.; Phang, J.; Laprairie, R.B.; Zhang, Y. Cannabinoids as an Emerging Therapy for Posttraumatic Stress Disorder and Substance Use Disorders. J. Clin. Neurophysiol. 2020, 37, 28-34. [CrossRef]

44. Moher, D.; Liberati, A.; Tetzlaff, J.; Altman, D.G.; Altman, D.; Antes, G.; Atkins, D.; Barbour, V.; Barrowman, N.; Berlin, J.A.; et al. Preferred reporting items for systematic reviews and meta-analyses: The PRISMA statement. PLoS Med. 2009, 6, b2535. [CrossRef]

45. Guyatt, G.H.; Oxman, A.D.; Schünemann, H.J.; Tugwell, P.; Knottnerus, A. GRADE guidelines: A new series of articles in the Journal of Clinical Epidemiology. J. Clin. Epidemiol. 2011, 64, 380-382. [CrossRef]

46. Higgins, J.P.; Sterne, J.A.; Savovic, J.; Page, M.J.; Hróbjartsson, A.; Boutron, I.; Reeves, B.; Eldridge, S. A revised tool for assessing risk of bias in randomized trials. Cochrane Database Syst. Rev. 2016, 10, $29-31$.

47. Elms, L.; Shannon, S.; Hughes, S.; Lewis, N. Cannabidiol in the Treatment of Post-Traumatic Stress Disorder: A Case Series. J. Altern. Complement. Med. 2019, 25, 392-397. [CrossRef] [PubMed]

48. Smith, P.A.; Chan, S.; Blake, A.; Wolt, A.; Zhang, L.; Wan, B.A.; Zaki, P.; Lam, H.; Deangelis, C.; Slaven, M.; et al. Medical cannabis use in military and police veterans diagnosed with post-traumatic stress disorder (Ptsd). J. Pain Manag. 2017, 10, $397-405$.

49. Greer, G.R.; Grob, C.S.; Halberstadt, A.L. PTSD Symptom Reports of Patients Evaluated for the New Mexico Medical Cannabis Program. J. Psychoact. Drugs 2014, 46, 73-77. [CrossRef]

50. Bonn-Miller, M.O.; Boden, M.T.; Bucossi, M.M.; Babson, K.A. Self-reported cannabis use characteristics, patterns and helpfulness among medical cannabis users. Am. J. Drug Alcohol Abuse 2014, 40, 23-30. [CrossRef]

51. Reznik, I. Post-traumatic stress disorder and medical cannabis use: A naturalistic observational study. Eur. Neuropsychopharmacol. 2012, 22, S363-S364. [CrossRef]

52. Rabinak, C.A.; Blanchette, A.; Zabik, N.L.; Peters, C.; Marusak, H.A.; Iadipaolo, A.; Elrahal, F. Cannabinoid modulation of corticolimbic activation to threat in trauma-exposed adults: A preliminary study. Psychopharmacology 2020, 237, 1813-1826. [CrossRef] [PubMed] 
53. Krystal, J.H.; Davis, L.L.; Neylan, T.C.; Raskind, M.A.; Schnurr, P.P.; Stein, M.B.; Vessicchio, J.; Shiner, B.; Gleason, T.D.; Huang, G.D. It Is Time to Address the Crisis in the Pharmacotherapy of Posttraumatic Stress Disorder: A Consensus Statement of the PTSD Psychopharmacology Working Group. Biol. Psychiatry 2017, 82, e51-e59. [CrossRef] [PubMed]

54. Crippa, J.A.S.; Nogueira Derenusson, G.; Borduqui Ferrari, T.; Wichert-Ana, L.; Duran, F.L.S.; Martin-Santos, R.; Vinícius Simões, M.; Bhattacharyya, S.; Fusar-Poli, P.; Atakan, Z.; et al. Neural basis of anxiolytic effects of cannabidiol (CBD) in generalized social anxiety disorder: A preliminary report. J. Psychopharmacol. 2011, 25, 121-130. [CrossRef] [PubMed]

55. Pertwee, R.G. The diverse CB 1 and CB 2 receptor pharmacology of three plant cannabinoids: $\Delta$ 9-tetrahydrocannabinol, cannabidiol and $\Delta$ 9-tetrahydrocannabivarin. Br. J. Pharmacol. 2008, 153, 199-215. [CrossRef]

56. Pisanti, S.; Malfitano, A.M.; Ciaglia, E.; Lamberti, A.; Ranieri, R.; Cuomo, G.; Abate, M.; Faggiana, G.; Proto, M.C.; Fiore, D.; et al. Cannabidiol: State of the art and new challenges for therapeutic applications. Pharmacol. Ther. 2017, 175, 133-150. [CrossRef]

57. Hill, M.N.; Campolongo, P.; Yehuda, R.; Patel, S. Integrating Endocannabinoid Signaling and Cannabinoids into the Biology and Treatment of Posttraumatic Stress Disorder. Neuropsychopharmacology 2018, 43, 80-102. [CrossRef] [PubMed]

58. Raymundi, A.M.; Da Silva, T.R.; Sohn, J.M.B.; Bertoglio, L.J.; Stern, C.A. Effects of $\Delta$ 9-tetrahydrocannabinol on aversive memories and anxiety: A review from human studies. BMC Psychiatry 2020, 20. [CrossRef]

59. Hindocha, C.; Cousijn, J.; Rall, M.; Bloomfield, M.A.P. The Effectiveness of Cannabinoids in the Treatment of Posttraumatic Stress Disorder (PTSD): A Systematic Review. J. Dual Diagn. 2020, 16, 120-139. [CrossRef]

60. Oropeza, V.C.; Mackie, K.; Van Bockstaele, E.J. Cannabinoid receptors are localized to noradrenergic axon terminals in the rat frontal cortex. Brain Res. 2007, 1127, 36-44. [CrossRef]

61. Friedman, M.J.; Bernardy, N.C. Considering future pharmacotherapy for PTSD. Neurosci. Lett. 2017, 649, 181-185. [CrossRef] [PubMed]

62. Do Monte, F.H.; Souza, R.R.; Bitencourt, R.M.; Kroon, J.A.; Takahashi, R.N. Infusion of cannabidiol into infralimbic cortex facilitates fear extinction via CB1 receptors. Behav. Brain Res. 2013, 250, 23-27. [CrossRef]

63. Tull, M.T.; McDermott, M.J.; Gratz, K.L. Marijuana dependence moderates the effect of posttraumatic stress disorder on trauma cue reactivity in substance dependent patients. Drug Alcohol Depend. 2016, 159, 219-226. [CrossRef] [PubMed]

64. Breivogel, C.S.; Sim-Selley, L.J. Basic neuroanatomy and neuropharmacology of cannabinoids. Int. Rev. Psychiatry 2009, 21, 113-121. [CrossRef]

65. Gunduz-Cinar, O. The endocannabinoid system in the amygdala and modulation of fear. Prog. Neuro-Psychopharmacol. Biol. Psychiatry 2021, 105. [CrossRef] [PubMed]

66. Berardis, D.; Marini, S.; Serroni, N.; Iasevoli, F.; Tomasetti, C.; Bartolomeis, A.; Mazza, M.; Tempesta, D.; Valchera, A.; Fornaro, M.; et al. Targeting the Noradrenergic System in Posttraumatic Stress Disorder: A Systematic Review and Meta-Analysis of Prazosin Trials. Curr. Drug Targets 2015, 16, 1094-1106. [CrossRef]

67. Chagas, M.H.N.; Crippa, J.A.S.; Zuardi, A.W.; Hallak, J.E.C.; MacHado-De-Sousa, J.P.; Hirotsu, C.; Maia, L.; Tufik, S.; Andersen, M.L. Effects of acute systemic administration of cannabidiol on sleep-wake cycle in rats. J. Psychopharmacol. 2013, 27, 312-316. [CrossRef] [PubMed]

68. Hsiao, Y.T.; Yi, P.L.; Li, C.L.; Chang, F.C. Effect of cannabidiol on sleep disruption induced by the repeated combination tests consisting of open field and elevated plus-maze in rats. Neuropharmacology 2012, 62, 373-384. [CrossRef] [PubMed]

69. Murillo-Rodríguez, E.; Palomero-Rivero, M.; Millán-Aldaco, D.; Mechoulam, R.; Drucker-Colín, R. Effects on sleep and dopamine levels of microdialysis perfusion of cannabidiol into the lateral hypothalamus of rats. Life Sci. 2011, 88, 504-511. [CrossRef]

70. Carlini, E.A.; Cunha, J.M. Hypnotic and antiepileptic effects of cannabidiol. J. Clin. Pharmacol. 1981, 21. [CrossRef]

71. Murillo-Rodríguez, E.; Millán-Aldaco, D.; Palomero-Rivero, M.; Mechoulam, R.; Drucker-Colín, R. Cannabidiol, a constituent of Cannabis sativa, modulates sleep in rats. FEBS Lett. 2006, 580, 4337-4345. [CrossRef]

72. Suraev, A.S.; Marshall, N.S.; Vandrey, R.; McCartney, D.; Benson, M.J.; McGregor, I.S.; Grunstein, R.R.; Hoyos, C.M. Cannabinoid therapies in the management of sleep disorders: A systematic review of preclinical and clinical studies. Sleep Med. Rev. 2020, 53. [CrossRef]

73. Tham, M.; Yilmaz, O.; Alaverdashvili, M.; Kelly, M.E.M.; Denovan-Wright, E.M.; Laprairie, R.B. Allosteric and orthosteric pharmacology of cannabidiol and cannabidiol-dimethylheptyl at the type 1 and type 2 cannabinoid receptors. Br. J. Pharmacol. 2019, 176, 1455-1469. [CrossRef] [PubMed]

74. Murillo-Rodríguez, E. The role of the CB1 receptor in the regulation of sleep. Prog. Neuro-Psychopharmacol. Biol. Psychiatry 2008, 32, 1420-1427. [CrossRef] [PubMed]

75. Zalai, D.; Chung, S.; Hussain, N.; Shapiro, C. Does cannabinoid really improve sleep? Testing the sleep effects of nabilone in chronic pain patients: A placebo-controlled, randomized, pilot study. Psychother. Psychosom. 2015, 84, 81.

76. Baron, E.P. Medicinal Properties of Cannabinoids, Terpenes, and Flavonoids in Cannabis, and Benefits in Migraine, Headache, and Pain: An Update on Current Evidence and Cannabis Science. Headache 2018, 58, 1139-1186. [CrossRef]

77. Sihota, A.; Smith, B.K.; Ahmed, S.; Bell, A.; Blain, A.; Clarke, H.; Cooper, Z.D.; Cyr, C.; Daeninck, P.; Deshpande, A.; et al. Consensus-Based Recommendations for Titrating Cannabinoids and Tapering Opioids for Chronic Pain Control. Int. J. Clin. Pract. 2020, 2020, e13871.

78. Manz, J.; Hyakutake, M.; Kelly, E. Calling for Openness to the Study of Cannabis Use in Chronic Pelvic Pain. J. Obstet. Gynaecol. Can. 2020. [CrossRef] 
79. Chaves, C.; Bittencourt, P.C.T.; Pelegrini, A. Ingestion of a THC-Rich Cannabis Oil in People with Fibromyalgia: A Randomized, Double-Blind, Placebo-Controlled Clinical Trial. Pain Med. 2020, 21, 2212-2218. [CrossRef] [PubMed]

80. Orsolini, L.; Chiappini, S.; Volpe, U.; De Berardis, D.; Latini, R.; Papanti, G.D.; Corkery, J.M. Use of medicinal cannabis and synthetic cannabinoids in post-traumatic stress disorder (PTSD): A systematic review. Medicina 2019, 55, 525. [CrossRef]

81. Bonn-Miller, M.O.; Babson, K.A.; Vandrey, R. Using cannabis to help you sleep: Heightened frequency of medical cannabis use among those with PTSD. Drug Alcohol Depend. 2014, 136, 162-165. [CrossRef]

82. Earleywine, M.; Bolles, J.R. Marijuana, Expectancies, and Post-Traumatic Stress Symptoms: A Preliminary Investigation. J. Psychoact. Drugs 2014, 46, 171-177. [CrossRef]

83. Shalev, A.; Liberzon, I.; Marmar, C. Post-Traumatic Stress Disorder. N. Engl. J. Med. 2017, 376, 2459-2469. [CrossRef] [PubMed]

84. Shorter, D.; Hsieh, J.; Kosten, T.R. Pharmacologic management of comorbid post-traumatic stress disorder and addictions. Am. J. Addict. 2015, 24, 705-712. [CrossRef]

85. Tandon, R.; Keshavan, M.S.; Nasrallah, H.A. Schizophrenia, "just the facts"; What we know in 2008. 2. Epidemiology and etiology. Schizophr. Res. 2008, 102,1-18. [CrossRef]

86. Korem, N.; Zer-Aviv, T.M.; Ganon-Elazar, E.; Abush, H.; Akirav, I. Targeting the endocannabinoid system to treat anxiety-related disorders. J. Basic Clin. Physiol. Pharmacol. 2016, 27, 193-202. [CrossRef] [PubMed]

87. Elliott, L.; Golub, A.; Bennett, A.; Guarino, H. PTSD and Cannabis-Related Coping Among Recent Veterans in New York City. Contemp. Drug Probl. 2015, 42, 60-76. [CrossRef] [PubMed]

88. Loflin, M.J.; Babson, K.A.; Bonn-Miller, M.O. Cannabinoids as therapeutic for PTSD. Curr. Opin. Psychol. 2017, 14, 78-83. [CrossRef] [PubMed] 